\title{
The Role of Water at Multiple Scales in Biotransport
}

$$
\begin{gathered}
\text { バイオトランスポートにおけるマルチスケールでの } \\
\text { 水の役割 }
\end{gathered}
$$

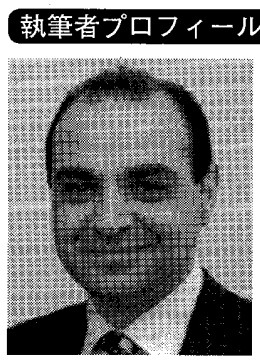

○1992 年中東工科大学（トルコ共和国）卒業（機 械工学), 1995 年同大修士号 (機械工学), 2002 年ミシガン州立大学博士号 (機械工学), 2005 よ り現職

（研究・専門テーマは, 生体熱力学, 生体熱・物質移 動

(O)ミネソタ大学助教授 機械工学科

(111 Church St. SE, Minneapolis, MN 55455 ,

U.S.A. /E-Mail :aaksan@me.umn.edu)

\section{アルプテキン アクサン}

Alptekin AKSAN

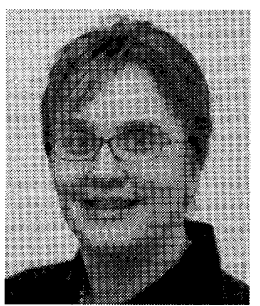

（1983 年アイオワ州立大学卒業（機械工学), 1985 年マサチューセッツエ科大学修士号 (機械工学), 1989 年同大博士号 (機械工学), 1996 年ミネソ 夕大学助教授 (臨床検査医学・病理学講座), 2002 より現職

○研究・尃門テーマは，生体の疑固

()ミミネンタ大学准教授 機械工学科

(111 Church St. SE, Minneapolis, MN 55455 , U.S.A. / E-Mail : hubel001@umn.edu)

\section{アリソン ハブル}

Allison HUBEL

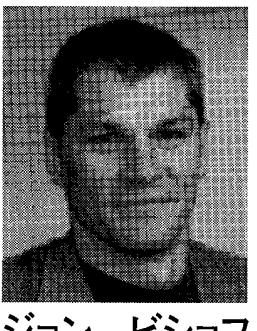

(2)1987 年カリフォルニア大学バークレー校卒業 (生体医工学), 1989 年カリフォルニア大学バー クレー校およびサンフランシスコ校修士号（生 体医工学)，1992 年 カリフォルニア大学バーク レー校博士号 (機械工学), 1993 年ミネソタ大学 助教授 (機械工学科), 1998 年同大准教授（機械 工学科), 2002 年より現職

○研究・専門テーマは，生体熱・物質移動，生体 における輸送現象

ジョン ビショフ

ミネソタ大学教授 機械工学科, 生体医工学科, 泌尿器科学講座

John BISCHOF (111 Church St. SE, Minneapolis, MN 55455

U.S.A. / E-Mail : bischof@umn.edu)
Major advances in medicine, engineering, basic science and biotechnology are fueling interest in transport phenomena at the molecular, cellular and tissue level. This mini-review highlights transport studies over multiple length scales and highlights the importance of water; it's interactions with surrounding molecules, movement and phase change in biological systems during preservation.

\section{Molecular-Level Phenomena}

\subsection{Water as a Structural Element}

Water has unique thermodynamic, chemical, and physical properties. These properties are significantly altered when it is interacting with, and in close proximity to biomolecules, membranes, and surfaces (e.g. hydration layer). Recent Molecular Dynamics simulations, ${ }^{(1)}$ and experiments conducted with confined water (where water was entrapped in nanopores) reveal that in the hydration layers, the translational diffusion of water is decreased by an $\mathrm{O}(4-5),{ }^{(2)}$ and its viscosity is increased by $\mathrm{O}(2-3),{ }^{(3)}$ when compared to the bulk. Its thermodynamic properties, such as the freezing temperature, are also significantly altered. ${ }^{(4)}$ These findings illustrate that on the molecular scale, water is a dynamically changing component of macromolecules and cell membranes.

1.2 New Focus: Macromolecular Motions and Membrane Hydration

Studies demonstrate that changes in hydration levels and solvent viscosity modifies the molecular motions of the macromolecules by modifying their energy landscape. ${ }^{(5)}$ Motions of the macromolecule are dictated by the rheological properties of the surrounding solution, ${ }^{(6,7)}$ and also by the motions of the water in its hydration layers. ${ }^{(5)}$ The fast local motions of macromolecules are found to be coupled to the fast local motions of the hydration shell, ${ }^{(8)}$ while its conformational motions are mainly dictated by the solvent viscosity. ${ }^{(5)}$ Using spectroscopic techniques two new low temperature transitions of macromolecules were recently discovered. The transition at $(180-260 \mathrm{~K})$ is directly attributed to reduction in hydration. ${ }^{(9)}$ This transition is called the "protein glass transition" since only solid-like motions are present below this temperature. Interestingly, this temperature is close to the fragile-to-strong transition temperature, ${ }^{(10)}$ and to the specific heat maxima ${ }^{(11)}$ of supercooled water $(\sim 220 \mathrm{~K})$. Our own research identified that at this temperature, the dynamics of proteins are coupled to the surrounding water (unpublished data).

Lipid-water interactions also influence the structure of the cell membrane. At the physiological temperature and hydration, the cell membrane exists predominantly in the fully-hydrated liquidcrystalline phase. With decreasing hydration or temperature, the 
distance between the lipids decrease and the membrane transitions into the gel state. ${ }^{(12)}$ Membrane phase change is not only confined to structural changes in the membrane (for example, the total area per lipid, ${ }^{(13)}$ membrane charge, lipid fluidity, and lipid phase separation $\left.{ }^{(14)}\right)$ but transmembrane transport of water and small solutes is also altered. ${ }^{(13)}$ Water diffusion and the diffusion of small solutes ${ }^{(15)}$ increases very significantly near the phase transition temperature and greatly diminishes in the gel phase. ${ }^{(16)}$ Recent research in our laboratories focused on understanding the effects of membrane phase change kinetics during cryopreservation processes and revealed the importance of membrane thermodynamic phase, transmembrane water transport, and the cellular water chemical potential on the viability of mammalian cells. ${ }^{(17)}$

The cytoskeleton plays a significant role in the structure, organization, and transitions of the cell membrane and thus its transport characteristics. ${ }^{(18)}$ For example, the phase transition temperature of the cell membrane when isolated from the cytoskeleton increases significantly from values observed in intact cells. ${ }^{(19)}$ These studies suggests that maintaining an optimal macromolecular hydration (lipid and protein) may be the molecular mechanism for the "two factor hypothesis" of cellular injury by intracellular ice and dehydration. ${ }^{(20)}$

\section{Cellular-Level Phenomena}

Measuring, modeling and characterizing water (solvent) and chemical (solute) transport during freezing on the cellular level have been an important engineering contribution to the field of cryopreservation and more broadly biotransport. The objective of this section is to summarize advances in water transport and small molecules known as cryoprotective agents (CPAs), which aid in preserving cells during freezing and drying, from 1988 to the present. Reviewers interested in more comprehensive review of historical studies of water and chemical transport and phase change should refer to refs. ${ }^{(21,22)}$

\subsection{New Experimental Methods}

Traditionally, cryomicroscopy or an electronic particle sizer has been used to quantify water transport in isolated cells. Curry and colleagues used a concentration dependent, self-quenching entrapped fluorophore to determine water content in sperm. ${ }^{(23)}$ Electron spin resonance (ESR) spectroscopy and magnetic resonance imaging has been used to quantify the water content of biological cells and the permeation of CPAs. ${ }^{(24,25)}$ Water transport in non-spherical and small cells has been correlated to Differential Scanning Calorimetry (DSC) and Fourier Transform Infra-red Spectroscopy (FTIR) measurements. ${ }^{(26,27)}$ Improved techniques for quantifying water content and permeation kinetics facilitates determination of transport barriers and the development of strategies to overcome them.

\subsection{Subcellular/Molecular Level Studies}

Both the transport of water and CPAs across the cell membrane has been assumed to be via passive diffusion through the lipid bilayer. Studies have demonstrated the presence of water-selective channels and even glycerol-specific transporters in the cell membrane (i.e. aquaporins). ${ }^{(28)}$ These studies suggest that water transport in cell membranes is highly selective and cotransport of CPAs and water is not typically observed. The transport characteristics of aquaporins have been used to alter the freezing response of cells that exhibit very low water permeability and are therefore refractive to cryopreservation. Edashige and colleagues induced transient expression of aquaporins in oocytes and embryos to modulate permeability and thereby improve post thaw recovery. ${ }^{(29)}$ Further manipulation of loading through the cell membrane is possible by using membrane pores ${ }^{(30)}$, holding cells at the lipid phase transition temperature $^{(31)}$, and direct injection. ${ }^{(32)}$

Recent studies have attempted to elucidate other molecular level phenomena that influences cellular level water transport. For example, Kreuzer-Martin and colleagues used different isotopes of water to establish that intracellular and extracellular water in E. coli represent two distinct pools of water. ${ }^{(33)}$ Molecular dynamic modeling was used to characterize the influence of DMSO on the lipid membrane. ${ }^{(34)}$ At low concentrations, DMSO thinned the cell membrane and increased membrane fluidity. At higher concentrations (the level typically used in cryopreservation), DMSO induced pore formation and increased membrane permeability.

\subsection{Theoretical Models for Water Transport}

Models developed by Mazur and Kedem and Katachalsky use non-equilibrium thermodynamics to characterize the transport of water and cryoprotective agents across the cell membrane. ${ }^{(35,36)}$ Water content during freezing or osmotic challenge has been predicted using these models and fit to experiments to quantify hydraulic permeability and its variation with temperature (see $\operatorname{ref}^{(22,37)}$ for summary). Water and CPA transport models can be combined with intracellular phase change modeling (ice vs. glass) for the purpose of predicting a freezing protocol. ${ }^{(38)}$ Molecular level studies have also influenced theoretical models for water transport. For example, the presence of water- or CPAspecific channels permits a simplification of the model of water and CPA transport developed by Kedem and Katachalsky. ${ }^{(39)}$

\section{Tissue and Bulk Level 3. Phenomena}

At the tissue level, both molecular and cellular events continue to be of importance along with new cell-cell and cellextracellular matrix interactions. These effects can add complexity and greatly influence the response.

\subsection{New Experimental Methods}

Clinical imaging techniques (i.e. magnetic resonance imaging (MRI), ultrasound (US) and computed tomography (CT)) as well as electrical impedance and light have all been used to measure the ice phase in tissues. ${ }^{(40)}$ In addition, MRI and CT can track CPA permeation and loading within tissues ${ }^{(41,42)}$, where CT has the additional advantage of being able to visualize crystalline vs. amorphous phases after cooling. ${ }^{(42)}$ The ability to monitor the spatial and temporal distribution of CPA and crystallization will facilitate the development of improved protocols for tissues. ${ }^{(43)}$ Optical techniques, such as confocal microscopy, have been used to visualize the three dimensional growth of ice crystals. ${ }^{(44)}$ Micro-patterning of cells has also been used to demonstrate the 
influence of cell adhesion and gap junctions on water transport and the propagation of ice into and between cells. ${ }^{(45) \sim(47)}$

\subsection{Cellular / Molecular Level Studies}

Detailed measurements of intracellular water have been achieved through low temperature electron microscopy methods (freeze-fracture, freeze-substitution, and cryo-SEM). ${ }^{(48)(49)}$ Ice forms first in continuous fluid spaces (e.g. vasculature). ${ }^{(49)}$ During freezing, the cell membrane can fuse and/or form new phases (Hex II), which are detrimental to survival. ${ }^{\left({ }^{(50)}\right.}$ Freezesubstitution and DSC on tissues have allowed quantification of water movement from the cells to the extracellular compartment and this movement has been shown to influence survival. ${ }^{(51)(52)}$ The movement of water from the extracellular space to the bulk solution can impact biomechanical and functional properties of the tissue. ${ }^{(53)}$

\subsection{Modeling}

The modeling of water / CPA transport in tissues is challenging and requires characterization of various resistances (i.e. the capillary membrane, interstitial space and cell membrane). Several multi-compartmental approaches have been reported, but none really elucidate the influence of these different compartments on transport (see ref $^{(54)}$ for review). Similarly, modeling of phase change in tissues also requires a multicompartment approach, although some work suggests that the bulk thermal problem can be de-coupled from the multicompartmental behavior as long as the thermal properties are known. ${ }^{(55)}$ Unfortunately, these properties are known for only a limited range of bulk systems and temperatures. ${ }^{\left({ }^{(5)}\right.}$

\section{Summary:}

Today, cells and tissues are needed for medical intervention (cell therapies and tissue engineering), or organisms are genetically engineered to produce specific macromolecules and perform complex chemical reactions (drug production, energy, sensing, bioremediation). Clinical and commercial application of these technologies depends upon our ability to preserve these systems. Our understanding of transport on the molecular, cellular and tissue level is integral to the development of effective preservation protocols for these systems.

（原稿受付 2007 年 12 月 22 日）

Refernces (文 献)

(1) A. Oleinikova, N. Smolin, and I. Brovchenko, Biophysical Journal 93, 2986-3000 (2007)

(2) K. Koga, H. Tanaka, and X. C. Zeng, Nature 408, 564-567 (2000).

( 3 ) T.-D. Li, J. Gao, R. Szoszkiewicz, U. Landman, and E. Riedo, Physical Review B 75, 115415 (2007).

(4) A. Schreiber, I. Ketelsen, and G. H. Findenegg, Physical Chemistry and Chemical Physics 3, 1185-1195 (2001).

(5) P. W. Fenimore, H. Frauenfelder, B. H. McMahon, and R. D. Young, Proceedings of the National Academy of Sciences of USA 101, 14408-14413 (2004).

(6) V. Reat, R. Dunn, M. Ferrand, J. L. Finney, R. M. Daniel, and J. C. Smith, Proceedings of the National Academy of Sciences of USA 97, 9961-9966 (2000)

(7) P. W. Fenimore, H. Frauenfelder, B. H. McMahon, and F. G. Parak, Proceedings of the National Academy of Sciences of USA 99, 16047-16051 (2002)

(8) J. Swenson, H. Jansson, and R. Bergman, Physical Review Let- ters 96, 247802 (2006)

9) K. Wood, M. Plazanet, F Gabel, B. Kessler, D. Oesterhelt, D. J. Tobias, G. Zaccai, and M. Weik, Proceedings of the National Academy of Sciences of USA 104, 18049-18054 (2007).

(10) A. Faraone, L. Liu, C.-Y. Mou, C.-W. Yen, and S.-H. Chen, Journal of Chemical Physics 121, 10843-10846 (2004).

(11) D. M. Murphy and T. Koop, Quarterly journal of the Royal Meteorological Society 131, 1539-1565 (2005)

(12) D. K. Hincha and M. Hagemann, Biochemical Journal 383, 277-283 (2004).

(13) L. Cruzeiro-Hanson and O. G. Mouritsen, Biochimica et Biophysica Acta 944, 63-72 (1988).

(14) G. Bryant, J. M. Pope, and J. Wolfe, European Biophysics Journal 21, 223-232 (1992).

(15) D. Papahadjopoulos, K. Jacobson, S. Nir, and T. Isca, Biochimica et Biophysica Acta 311, 330-348 (1973).

(16) R. A. Garrick, B. C. Patel, and F. P. Chinard, Journal of American Physiological Society, C74-C80 (1982)

(17) W. F. Wolkers, S. K. Balasubramanian, E. L. Ongstad, H. C. Zec, and J. C. Bischof, Biochimica et Biophysica Acta 1768, 728-736 (2007).

(18) A. P. Liu and D. A. Fletcher, Biophysical Journal 91, 4064-4070 (2006).

(19) C. Laroche, H. Simonin, L. Beney, and P. Gervais, Biochimica et Biophysica Acta 2005, 8-16 (2005).

(20) P. Mazur, S. P. Leibo, and E. H. Chu, Exp Cell Res 71, 345-355 (1972).

(21) K. R. Diller, Cryobiology 34, 304-314 (1997).

(22) J. J. McGrath, Cryobiology 34, 315-334 (1997).

(23) M. R. Curry, F. W. Kleinhans, and P. F. Watson, Cryobiology 41, 167-173 (2000)

(24) M. Hagedorn, E. W. Hsu, U. Pilatus, D. E. Wildt, W. R. Rall, and S. J. Blackband, Proc Natl Acad Sci U S A 93, 7454-7459. (1996).

(25) F. W. Kleinhans, V. S. Travis, J. Du, P. M. Villines, K. E. Colvin, and J. K. Critser, J Androl 13, 498-506 (1992).

(26) R. V. Devireddy, D. Raha, and J. C. Bischof, Cryobiology 36 124-155 (1998)

27) W. F. Wolkers, S. K. Balasubramanian, E. L. Ongstad, H. C. Zec and J. C. Bischof, Biochim Biophys Acta 1768, 728-736 (2007)

(28) A. S. Verkman, J Cell Sci 118, 3225-3232 (2005)

(29) K. Edashige, Y. Yamaji, F. W. Kleinhans, and M. Kasai, Biol Reprod 68, 87-94 (2003).

(30) S. S. Buchanan, S. A. Gross, J. P. Acker, M. Toner, J. F. Carpenter, and D. W. Pyatt, Stem Cells Dev 13, 295-305 (2004).

(31) G. R. Satpathy, Z. Torok, R. Bali, D. M. Dwyre, E. Little, N. J. Walker, F. Tablin, J. H. Crowe, and N. M. Tsvetkova, Cryobiology 49, 123-136 (2004).

(32) A. Eroglu, J. A. Lawitts, M. Toner, and T. L. Toth, Cryobiology 46, 121-134 (2003).

(33) H. W. Kreuzer-Martin, M. J. Lott, J. R. Ehleringer, and E. L. Hegg, Blochemistry 45, 13622-13630 (2006).

(34) A. A. Gurtovenko and J. Anwar, J Phys Chem B 111, 10453-10460 (2007).

(35) O. Kedem and A. Katchalsky, Biochem. et Biophys. Acta 27, 229-256 (1958).

(36) P. Mazur, J. Gen. Physiol 47, 347-369 (1963)

(37) X. He and J. C. Bischof, Crit Rev Biomed Eng 31, 355-422 (2003).

38) J. O. Karlsson, A. Eroglu, T. L. Toth, E. G. Cravalho, and M. Toner, Hum Reprod 11, 1296-1305. (1996).

(39) F. W. Kleinhans, Cryobiology 37, 271-289 (1998)

(40) B. Rubinsky, Annu Rev Biomed Eng 2, 157-187 (2000).

(41) N. P. Bidault, B. E. Hammer, and A. Hubel, Cryobiology 40 , 13-26 (2000)

(42) J. C. Bischof, B. Mahr, J. H. Choi, M. Behling, and D. Mewes, Ann Biomed Eng 35, 292-304 (2007).

(43) G. M. Fahy, B. Wowk, J. Wu, J. Phan, C. Rasch, A. Chang, and E. Zendejas, Cryobiology 48, 157-178 (2004).

(44) H. Ishiguro and K. Koike, Ann N Y Acad Sci 858, 235-244 (1998).

(45) J. P. Acker, J. A. Elliott, and L. E. McGann, Biophys J 81 1389-1397 (2001).

(46) S. K. Balasubramanian, J. C. Bischof, and A. Hubel, Cryobiology $52,62-73$ (2006)

(47) D. Irimia and J. O. Karlsson, Biophys J 82, 1858-1868 (2002).

(48) S. Fujikawa, J Cell Sci 49, 369-82 (1981)

(49) B. Rubinsky, C. Y. Lee, J. Bastacky, and G. Onik, Cryobiology 27, 85-97 (1990)

(50) W. J. Gordon-Kamm and P. L. Steponkus, Proc Natl Acad Sci U S A 81, 6373-6377 (1984).

(51) P. Pazhayannur, J.C. Bischof, ASME J. Biomech Engr 119 , 269-277 (1997)

(52) M. R. Neidert, R. V. Devireddy, R. T. Tranquillo, and J. C. Bischof, Tissue Eng 10, 23-32 (2004).

(53) R. T. Venkatasubramanian, E. D. Grassl, V. H. Barocas, D. Lafontaine, and J. C. Bischof, Ann Biomed Eng 34, 823-832 (2006).

(54) B. Han and J. C. Bischof, Cell Preservation Technology 2, 91-112 (2004).

(55) R. V. Devireddy, D. J. Smith, and J. C. Bischof, ASME Journal of Heat Transfer 124, 365-374 (2002).

(56) J. W. Choi and J. C. Bischof, In.t J. of Heat and Mass Transfer (In Press) (2007). 